\title{
Education and Training of Future Managers for Sustainable Development in the V4 Countries
}

\author{
Helena Harausová \\ Dept. of Social Sciences, Faculty of Public Administration, University of P. J. Šafárik \\ Popradská 66, Košice, Slovakia \\ Email: helena.harausova@upjs.sk \\ Jana Chovancová \\ Dept. of Environmental Management, Faculty of Management, University of Prešov in \\ Prešov 17. novembra 1, Prešov, Slovakia \\ Email: jana.chovancova@unipo.sk
}

Doi:10.5296/ijhrs.v5i1.7074

URL: http://dx.doi.org/10.5296/ijhrs.v5i1.7074

\begin{abstract}
Impact of companies and their activities on the environment has become a subject of growing interest since the late 80 s of the last century, especially in the western economies. The growing interest in the implementation of environmentally friendly practices in business practice directly correlates with the need for education and training of future managers to sustainable development. The presented paper analyses the need for environmental education of graduates who are expected to act as executives and in positions which are defined as Green enhanced skills occupations or shortly Green jobs and who should be able to apply the tools of environmental policy in a business sector, municipalities or third sector. The essential part of the paper presents partial results of the survey, conducted among students of business schools, with the aim to determine the level of awareness about selected voluntary instrument of environmental policy as well as their perception of the need for environmental education . The article also contains proposals for a system of education for sustainable development in business schools.
\end{abstract}

Keywords: Sustainable development, Environmental policy tools, Future managers, Education, Education system

\section{Introduction}

The need for more environmentally friendly practices in business practice and competitive advantages associated with them is quite frequently discussed in the literature. Many organisations that are involved in environmental initiatives aimed at improving their environmental performance highlight the benefits associated with this approach, whether in the form of financial savings, reduced risk or improvement of the company's goodwill. With the transformation of the organisation to environmentally conscious and responsible, however, 
a number of restrictions and barriers associated with corporate culture and change management occur. To overcome these limitations, literature recommends and points to the importance of environmental education of members or employees of the organisation. Environmentally educated and conscious managers and employees understand how their actions and decisions can be influenced and how they influence the environment. Especially in this area business schools play an important role, just because they educate a new generation of future managers, who will be expected to lead their organisations sustainably in economic, social as well as environmental context.

\subsection{Education and training for sustainable development}

A broader concept of environmental education can be found in several documents of international and national importance. The most important are the Lisbon Strategy (revised in 2005), where one of the priorities is "more investment in environmental education and innovation," Europe 2020 - a 10-year strategy, which follows the Lisbon Strategy and the EU Strategy for Sustainable Development (revised in r. 2009), where environmental education is considered an important tool for ensuring a transition to sustainable production and consumption. On the basis of these strategies the documents at the national level within the EU Member States have been implemented.

In Slovakia, this concept is implemented via the document "Concept of environmental education at all levels of education in the Slovak Republic and the system of lifelong learning" and its action plan "Action Plan for Education and Training for Sustainable Development in SR" both adopted in 2006; in the Czech Republic there is "Strategy of Education for Sustainable Development for the period 2008 - 2015" applying the basic principles and issues of sustainable development into education in schools of all types; in Poland it is "National Strategy for Environmental Education" (Narodowa Strategia Edukacji Ekologiczna); as well in Hungary "National Strategy for Environmental Education" (Nemzeti Környezeti Nevelési Strategy).

Another important document that influences environmental education at international level is Agenda 21, adopted by the UN in 1992, which elaborates the principles of sustainable development - Chapter 36 of this Agenda describes a promotion of education and public awareness and training programs for sustainable development as well as other national and international obligations. Agenda 21 (1992) states: "Education can give people the environmental and ethical awareness, values and attitudes, skills and behaviour needed for sustainable development. To do this, education needs to explain not only the physical and biological environment, but the socio-economic environment and human development".

A tradition of national conferences focused on the issues of environmental education at all types of schools in Slovak Republic is held since 1994. The results and conclusions from these events have created a set of recommendations for universities, and universities of the third age as well as for primary and secondary schools, pre-schools, and interests and extracurricular activities. Conferences aim to professionally contribute to the determination of Conceptual bases of education for sustainable development with an emphasis on finding links to natural, cultural and spiritual values of Slovakia. Conclusions and recommendations of these conferences are the basis for the working group of the Ministry of Education, which 
is responsible for the implementation of the UNECE Strategy for Education for Sustainable Development.

\subsection{Education and training for sustainable development at universities}

(Hilbert, 2007) states that the saturation of the issues of education for sustainable development can be grouped according to accredited study fields and their programs as follows:

- Universities focused on environmental and ecological fields, pedagogically focused (preparation of professionals for education and training),

- Universities focused on environmental and ecological fields (not pedagogically focused)

- Universities focused on pedagogy, including ecological and environmental fields in combination with other courses,

- Universities focused on pedagogy, with focus on the economic pillar of sustainable development and regional development,

- Universities focused on socio - economic pillar,

- Universities focused on providing education via environmental, ecological issues, related to their professional focus.

Education and training of professionals in sub-pillars of sustainable development is saturated within the accredited study programs, but does not reflect the multidisciplinary nature of education towards sustainable development.

Therefore there occurs a question of implementation of education for sustainable development also to study fields and programs, which are not eminently environmentally focused. To this category can be included also economic and managerial study fields and study programmes. The authors believe that managers and economists represent a significant group whose decisions can have direct or indirect, positive or negative impact on the implementation of sustainable development in practice. Hence there is a need to change the concept of education of future managers and integration of sustainable development into existing curricula.

The theme of environmental education of managers is handled by various Slovak authors, including e.g. Majerník (2006, 2008), Halašová (2009), Huttmanová (2009), Adamišin (2012), Fazekašová (2007), Terek (2009), and Jurková, Ferencová (2013) and others, as well as many foreign authors, e.g. Azapagic (2004), Rands, (2009), Ward (1999), Orr (1992, 1994), Krasny (2010) and others. Two special issues of business journals have focused on increasing attention to environmental issues in business education: (1) The Journal of Teaching in International Business, contained nine articles that raised issues and offered suggestions for faculty to consider incorporating environmental issues into the business curriculum and (2) Journal of Management education devoted to addressing the natural environment in management education. Its eight articles provide conceptual frameworks, pedagogical approaches, case studies, course curriculums, exercises and activities for use in integrating environmental issues into existing courses or in developing stand-alone courses devoted to sustainable development.

Authors of above mentioned articles suggest that environmental education of managers 
should foster awareness, understanding and concern that motivate students to take action in their personal and organisational lives that facilitate environmentally sustainable behaviour.

Rands (2009) deals with this issue as well and refers to the principle of personal responsibility, through which individuals contribute to sustainable development. Managers, as well as future managers can be seen as a group of individuals who have a lot of power and responsibilities. Therefore, environmental education and education for sustainable development of managers can be seen as key to implementing the principles of sustainable development into practice.

Halašová, M. (2009) states, that educational goal of sustainable development should include broadening the knowledge, development of special behaviour, intellect, forming of life attitudes and values, which should be considered also in environmental education of future managers.

\subsection{Two directions of implementation of education for sustainable development}

Vošahlíková (2011 b) states that when watching how the concept of education for sustainable development penetrates the curriculum, we focus on two streams of the process of its implementation into practice. The first stream flows from international documents through national strategies to local projects. This process can be described as top-down implementation (i.e. implementation acting from above). For this implementation is typical that in the first phase it offers a wide range of measures and sub themes. From this menu the individual regions, countries, different communities and individuals can select such topics and objectives that are relevant to the issues and problems that are currently being solved. Education for sustainable development in the final phase of the implementation shall take as many forms and shapes, as subjects are involved.

At the level of implementation of the partial targets, the top-down implementation ideally meets the second direction of action of the process, called bottom-up implementation (i.e. implementation acting from below). The implementation of this initiative resides in the initiative of educational institutions, teachers, or non-profit organisations. In contrast to the top-down implementation, the bottom-up implementation focuses from the beginning on specific thematic projects and themes of education for sustainable development. It can include projects and topics realised by e.g. nurseries, elementary schools, high schools, universities and non-profit organisations. The significance of bottom-up implementation lies in the concretisation of the general goals of education for sustainable development for specific audiences and creative handling of topics that are relevant to them. Both streams influence, complement and strengthen each other. Documents concentrated in the process of top-down implementation are a source of guidance and inspiration for the overall objectives and themes. In the process of bottom-up implementation various methodical approaches to sustainable development are created and the concept of sustainable development is accepted by the general public.

On the present the requirements for qualification of graduates of all types of schools are changing. Issues of so called Green jobs are getting to the fore. Bellan (2010) states that the quantitative changes in the labour market are accompanied with qualitative changes, in particular changes related to qualification requirements. Greening of economy pursues three basic types of the qualification effects: on increase in demand for jobs with the same 
qualifications, job changes in given scale and level of qualifications needed, create new jobs with entirely new qualification requirements.

In connection with these changes in the labour market and the emergence of green jobs universities can play an important role in education of future managers especially via comprehensive education of the topic of sustainable development and tools of environmental policy.

\subsection{Environmental Policy Tools}

Development of opinions for solution of the problems of sustainable development was reflected in the EU policy, where a broad spectrum of tools was established, which can be used by organisations and managers to improve their environmental performance.

Teplická (2007) divides the environmental policy tools into two groups:

- Product oriented tools - highlight the quality of the products and their environmental profile. Environmentally friendly products should represent credible information for the consumer, which may influence the decision to purchase them.

- Process oriented tools - reflect the quality of the environment through a changed approach of a company toward process with negative impact on the environment.

The product oriented tools include: EL - Eco Labelling, LCA-Life Cycle Assessment, IPP Integrated Product Policy, ED - Eco-Design, GP - Green Procurement.

The process oriented tools include: EMAS - Eco-Management and Audit Scheme, EMS Environmental Management System, EA - Environmental Auditing, EMA - Environmental Management Accouting, EPE - Environmental Performance Evaluation, CP - Cleaner Production.

Chovancová (2012) states the most known and widely used tools: Environmental management systems (EMS) according to ISO 14001, Eco-management and audit scheme (EMAS), cleaner production, Corporate social responsibility (CSR) etc. Their implementation in the corporate (and public) sphere is voluntary. Majerník, Chovancová, Hodolič (2009) state, that these tools are aimed for organisations, which want to valorise and improve their environmental behaviour, minimise negative influence on the community and environment, where they carry out their activities. Implementation of these tools requires financial investments and also support from the management and all employees. On the other hand, for the organisation, these investments can gain better position on the market, improve relations with other parties and other important added values. This requires the present as well as future managers to master these tools not only theoretically, but also they should have enough knowledge and skills for their application in practice. Here the universities in different countries play an important role.

\section{Research}

The main objective of the research was to determine the level of knowledge about the environmental policy tools among the students who study at business schools in V4 countries i.e. Slovakia, Poland, Hungary and the Czech Republic. Within the main objective it was also studied, the students of which country have the greatest knowledge about the environmental 
policy tools, which tool they know the best or do not know at all. The sub-goals of the research were to determine whether the students feel the urge to educate themselves in the field of environmental protection and whether there is a significant correlation between the level of knowledge about the various environmental policy tools and the need be educated, whether there is a significant dependence of the level of knowledge and the efforts to motivate the future subordinates to environmental protection.

The research was conducted from September 2011 to October 2013. 115 Slovak, 100 Polish, 96 Hungarian and 114 Czech students participated in the research. This sample is representative with respect to the number of students who study at universities of managerial focus (business schools). Students were not chosen at random; only those were addressed who were assumed to complete the questionnaire. Only the postgraduate students were addressed who were assumed to encountered problems of sustainable development during their studies. An average sample of surveyed students from V4 countries is 106 students. Differences in the number of students compared to the average are not so significant so that they would significantly affect the results of the research. Data collection questionnaire was used in printed and electronic form. The comparative analysis and the methods of descriptive and inductive statistics were used to compare the results of the research.

Table 1: Frequency

\begin{tabular}{|l|c|c|c|c|c|}
\hline & $\mathrm{N}$ & Minimum & Maximum & Mean & Std. Deviation \\
\hline Frequency & 4 & 96 & 115 & 106,25 & 9,674 \\
$\begin{array}{l}\text { Valid N } \\
\text { (listwise) }\end{array}$ & 4 & & & & \\
\hline
\end{tabular}

Case Summaries $^{\mathrm{a}}$

\begin{tabular}{|l|l|l|l|l|l|l|}
\hline SK & PL & HU & CZ & Total N & Variance & Mean \\
\hline 115 & 100 & 96 & 114 & 4 & 93,583 & 106,25 \\
\hline
\end{tabular}

${ }^{a}$ Limited to first 100 cases.

To determine the level of knowledge, the following best known environmental policy tools were selected: the system of environmental management according to ISO 14001, European Union regulation on environmental management and audit scheme EMAS, product life cycle assessment LCA, evaluation of environmental performance, social responsibility of organisations and environmental labelling of products - ecolabelling EL. The choice of tools was made on the assumption that these are predominantly tools implemented at the strategic level in the company and managers should be familiar with their structure, process of implementation, potential benefits and barriers to their implementation. The students had an opportunity to express themselves by using the Likert scale - there were five options available: definitely yes, yes, I do not know, no, definitely no. The answer "definitely yes" was assigned 
a value of 5 (most knowledge), answer "yes" a value of 4, answer "I do not know" a value of 3 , answer "no" a value of 2 and answer "definitely no" a value of 1 (least knowledge).

\subsection{Evaluation of research results}

Research question: What is the level of knowledge about the chosen the environmental policy tool among students from each of the V4 countries, that is Slovakia, Poland, Hungary and the Czech Republic. The answer to this question was sought by descriptive statistics. The results are documented through frequency tables. Students from each country have been assessed separately and consequently, the comparative analysis aimed to determine the order of the level of knowledge among students from the V4 countries was performed.

\subsubsection{Slovak students}

The results of the level of knowledge about environmental policy tools are documented in Table 2

Table 2: Slovak students

\begin{tabular}{|l|l|l|l|l|l|l|l|l|l|l|l|l|l|}
\hline & & & & & Lower & Upper & $\begin{array}{l}\text { Quar } \\
\text { tile }\end{array}$ & & & Std.Err. & & Std.Err. \\
\hline & $\begin{array}{l}\text { Valid } \\
\mathrm{N}\end{array}$ & Mean & $\begin{array}{l}\text { Me } \\
\text { dian }\end{array}$ & Min & Max & $\begin{array}{l}\text { Quar } \\
\text { tile }\end{array}$ & $\begin{array}{l}\text { Quar } \\
\text { tile }\end{array}$ & Range & $\begin{array}{l}\text { Std. } \\
\text { Dev. }\end{array}$ & Skewness & Skewness & Kurtosis & Kurtosis \\
\hline ISO & 115 & 2,99 & 3 & 1 & 5 & 2 & 4 & 2 & 1,188 & 0,01702 & 0,225511 & $-0,8875$ & 0,44738 \\
\hline EMAS & 115 & 3,80 & 4 & 1 & 5 & 3 & 5 & 2 & 1,050 & $-0,85492$ & 0,225511 & 0,2400 & 0,44738 \\
\hline LCA & 115 & 3,88 & 4 & 1 & 5 & 3 & 5 & 2 & 1,137 & $-0,68401$ & 0,225511 & $-0,6809$ & 0,44738 \\
\hline EPE & 115 & 2,95 & 3 & 1 & 5 & 2 & 4 & 2 & 1,071 & 0,21845 & 0,225511 & $-0,7008$ & 0,44738 \\
\hline EL & 115 & 2,66 & 2 & 1 & 5 & 2 & 4 & 2 & 1,295 & 0,36889 & 0,225511 & $-0,9820$ & 0,44738 \\
\hline CSR & 115 & 2,47 & 2 & 1 & 5 & 2 & 3 & 1 & 1,216 & 0,55731 & 0,225511 & $-0,5198$ & 0,44738 \\
\hline
\end{tabular}

Source: own research

Slovak students have the most knowledge about social responsibility of organisations. Knowledge about this tool reached level 2, 47. The least knowledge they have about the assessment of the product life cycle with a value of 3.88. Individual data is not evenly distributed in EMAS, LCA, EL and CSR, therefore, it is necessary for the further analysis to use non-parametric statistical tests. 


\section{MInstitute ${ }_{\text {Macrothink }}$}

International Journal of Human Resource Studies

ISSN 2162-3058

2015, Vol. 5, No. 1

\subsubsection{Polish students}

The results of the level of knowledge about environmental policy tools are documented in

Table 3.

Table 3 Poland students

\begin{tabular}{|l|l|l|l|l|l|l|l|l|l|l|l|l|l|}
\hline & & & & & Lower & Upper & $\begin{array}{l}\text { Quar } \\
\text { tile }\end{array}$ & & & Std.Err. & & Std.Err. \\
\hline & $\begin{array}{l}\text { Valid } \\
\mathrm{N}\end{array}$ & Mean & $\begin{array}{l}\text { Me } \\
\text { dian }\end{array}$ & Min & Max & $\begin{array}{l}\text { Quar } \\
\text { tile }\end{array}$ & $\begin{array}{l}\text { Quar } \\
\text { tile }\end{array}$ & Range & $\begin{array}{l}\text { Std. } \\
\text { Dev. }\end{array}$ & Skewness & Skewness & Kurtosis & Kurtosis \\
\hline ISO & 100 & 2,75 & 3 & 1 & 5 & 2 & 4 & 2 & 1,336 & 0,31595 & 0,24138 & $-1,0006$ & 0,47833 \\
\hline EMAS & 100 & 3,11 & 3 & 1 & 5 & 2 & 4 & 2 & 1,324 & $-0,04646$ & 0,24138 & $-1,1742$ & 0,47833 \\
\hline LCA & 100 & 2,99 & 3 & 1 & 5 & 2 & 4 & 2 & 1,321 & 0,04547 & 0,24138 & $-1,0920$ & 0,47833 \\
\hline EPE & 100 & 2,10 & 2 & 1 & 5 & 1 & 3 & 2 & 1,184 & 0,955331 & 0,24138 & $-0,0336$ & 0,47833 \\
\hline EL & 100 & 1,95 & 2 & 1 & 5 & 1 & 2 & 1 & 1,048 & 1,336842 & 0,24138 & 1,6495 & 0,47833 \\
\hline CSR & 100 & 2,44 & 2 & 1 & 5 & 1 & 3,5 & 2,5 & 1,305 & 0,578938 & 0,24138 & $-0,8422$ & 0,47833 \\
\hline
\end{tabular}

Source: own research

Polish students have the most knowledge about environmental labelling of products Ecolabelling EL whose value was 1.95. The least knowledge they have about European Union Regulations on environmental management and audit scheme EMAS with a value of 3.11. Even among Polish students there is different data unevenly distributed; therefore, non-parametric statistical tests will be used in the subsequent analysis.

\subsubsection{Hungarian students}

The results of the level of knowledge about environmental policy tools are documented in Table 4.

Table 4 Hungarian students

Source: own research

\begin{tabular}{|c|c|c|c|c|c|c|c|c|c|c|c|c|c|}
\hline & & & & & & Lower & Upper & $\begin{array}{l}\text { Quar } \\
\text { tile }\end{array}$ & & & Std.Err. & & Std.Err. \\
\hline & $\begin{array}{l}\text { Valid } \\
\mathrm{N}\end{array}$ & Mean & $\begin{array}{l}\mathrm{Me} \\
\text { dian }\end{array}$ & Min & Max & $\begin{array}{l}\text { Quar } \\
\text { tile }\end{array}$ & $\begin{array}{l}\text { Quar } \\
\text { tile }\end{array}$ & Range & $\begin{array}{l}\text { Std. } \\
\text { Dev. }\end{array}$ & Skewness & Skewness & Kurtosis & Kurtosis \\
\hline ISO & 96 & 3,07 & 3 & 1 & 5 & 2 & 4 & 2 & 1,485 & $-0,13309$ & 0,235724 & $-1,2887$ & 0,46731 \\
\hline EMAS & 96 & 3,89 & 4 & 1 & 5 & 3 & 5 & 2 & 1,184 & $-1,06856$ & 0,235724 & 0,4621 & 0,46731 \\
\hline LCA & 96 & 2,88 & 3 & 1 & 5 & 1 & 5 & 4 & 1,552 & 0,14695 & 0,235724 & $-1,3941$ & 0,46731 \\
\hline EPE & 96 & 2,58 & 3 & 1 & 5 & 2 & 3 & 1 & 1,261 & 0,39949 & 0,235724 & $-0,7269$ & 0,46731 \\
\hline EL & 96 & 2,49 & 2 & 1 & 5 & 1 & 3 & 2 & 1,352 & 0,43814 & 0,235724 & $-1,0105$ & 0,46731 \\
\hline CSR & 96 & 2,51 & 2 & 1 & 5 & 1 & 3 & 2 & 1,294 & 0,51040 & 0,235724 & $-0,7006$ & 0,46731 \\
\hline
\end{tabular}

Hungarian students have the most knowledge about environmental labelling of products Ecolabelling EL, whose value was 2.49. The least knowledge they have about European Union Regulations on environmental management and audit scheme EMAS with a value of 3.89. Also for Hungarian students, different data is unevenly distributed, 


\section{Macrothink}

therefore, non-parametric statistical $\mathrm{t}$ will be used in the subsequent analysis.

\subsubsection{Czech students}

The results of the level of knowledge about environmental policy tools are documented in Table 5.

Table 5 Czech students

\begin{tabular}{|l|l|l|l|l|l|l|l|l|l|l|l|l|l|}
\hline & & & & & Lower & Upper & $\begin{array}{l}\text { Quar } \\
\text { tile }\end{array}$ & & & Std.Err. & & Std.Err. \\
\hline & $\begin{array}{l}\text { Valid } \\
\text { N }\end{array}$ & Mean & $\begin{array}{l}\text { Me } \\
\text { dian }\end{array}$ & Min & Max & $\begin{array}{l}\text { Quar } \\
\text { tile }\end{array}$ & $\begin{array}{l}\text { Quar } \\
\text { tile }\end{array}$ & Range & $\begin{array}{l}\text { Std. } \\
\text { Dev. }\end{array}$ & Skewness & Skewness & Kurtosis & Kurtosis \\
\hline ISO & 114 & 3,23 & 3 & 1 & 5 & 2 & 4 & 2 & 1,3781 & $-0,1686$ & 0,22647 & $-1,3042$ & 0,44926 \\
\hline EMAS & 114 & 3,98 & 4 & 1 & 5 & 3 & 5 & 2 & 1,1287 & $-0,8670$ & 0,22647 & $-0,3786$ & 0,44926 \\
\hline LCA & 114 & 4,07 & 4 & 1 & 5 & 3 & 5 & 2 & 1,1266 & $-1,0470$ & 0,22647 & 0,0834 & 0,44926 \\
\hline EPE & 114 & 4,07 & 4 & 1 & 5 & 3 & 5 & 2 & 1,1108 & $-0,9291$ & 0,22647 & $-0,3873$ & 0,44926 \\
\hline EL & 114 & 2,64 & 2 & 1 & 5 & 1 & 4 & 3 & 1,6074 & 0,39528 & 0,22647 & $-1,4759$ & 0,44922 \\
\hline CSR & 114 & 2,21 & 2 & 1 & 5 & 1 & 3 & 2 & 1,1557 & 0,87281 & 0,22647 & 0,06524 & 0,44926 \\
\hline SOurcen
\end{tabular}

Source: own research

Czech students have the most knowledge about social responsibility of organisations. Knowledge of this tool reached level 2.21. The least knowledge they have about the assessment of the product life cycle with a value of 4.07 and the same value of the acquired level of knowledge when evaluating environmental performance. Individual data is not evenly distributed, it is therefore necessary for the further analysis to use non-parametric statistical tests.

Table 6: The average calculated values presenting the knowledge about the environmental policy tools

\begin{tabular}{|l|l|l|l|l|l|}
\hline Environmental policy tools & Slovak & Poland & Hungarian & Czech & Mean \\
\hline ISO 1400 & 2,99 & 2,75 & 3,07 & 3,23 & 2,45 \\
\hline EMAS & 3,80 & 3,11 & 3,89 & 3,98 & 3,69 \\
\hline LCA & 3,88 & 2,99 & 2,88 & 4,07 & 3,45 \\
\hline $\begin{array}{l}\text { Environmental Performance } \\
\text { Evaluation }\end{array}$ & 2,95 & 2,10 & 2,58 & 4,07 & 2,92 \\
\hline Ecolabeling & 2,66 & 1,95 & 2,49 & 2,64 & 2,43 \\
\hline Corporate Social Responsibility & 2,47 & 2,44 & 2,51 & 2,21 & 2,41 \\
\hline Mean & 3,12 & 2,55 & 2,90 & 3,36 & \\
\hline
\end{tabular}

Source: own research

Taking into account the calculated average, the most knowledgeable about the various environmental policy tools are the Polish students with an overall mean of 2.55. The Hungarian students who achieved the mean of 2.90 are in the second place. The third place is occupied by the Slovak students who achieved the mean of 3.12. The Czech students whose mean is 3.36 have the least knowledge about the environmental policy tools.

Polish students are the most knowledgable about every tool of environmental protection (except for the social responsibility of organisations) compared to their counterparts from 


\section{Mll Macrothink}

Slovakia, Czech Republic and Hungary. Students from these four countries have the greatest knowledge about the social responsibility of organisations (mean 2.41) and about the product ecolabeling with the mean of 2.43. Following is an environmental management system according to ISO 14001 with a mean of 2.45 , the environmental behaviour with a mean of 2.92 , the fourth position is occupied by the product life cycle assessment LCA with a mean of 3.45. Students from these countries have the least knowledge about the European Union Regulations on environmental management and audit scheme EMAS, which reached the lowest mean of 3.69. Considering that knowledge of the individual tools could take values from 1 to 5, so it can be concluded that the knowledge of students from Poland, Slovakia, the Czech Republic and Hungary is insufficient.

An achieved overall average value of the level of knowledge is 2.89 , what represents a below-average knowledge of the chosen environmental policy tool. Based on these values, the business schools could be recommended to include not only the subject of environmental protection tools in their curriculum, but also to teach the issue of environmental protection more complex.

The questionnaire offered students the opportunity to give their opinion on the statement: "As a manager I consider it necessary to be educated in the area of environmental protection." Also here they could answer within the five-point Likert scale. The results are documented in table 7.

Table 7 Perception of need of environmental education 


\begin{tabular}{|c|c|c|c|c|c|c|c|c|c|c|c|c|c|}
\hline \multicolumn{14}{|l|}{ SK } \\
\hline & & & & & & Lower & Upper & $\begin{array}{l}\text { Quar } \\
\text { tile }\end{array}$ & & & Std.Err. & & Std.Err. \\
\hline & $\begin{array}{l}\text { Valid } \\
\mathrm{N}\end{array}$ & Mean & $\begin{array}{l}\text { Me } \\
\text { dian }\end{array}$ & Min & Max & $\begin{array}{l}\text { Quar } \\
\text { tile }\end{array}$ & $\begin{array}{l}\text { Quar } \\
\text { tile }\end{array}$ & Range & $\begin{array}{l}\text { Std. } \\
\text { Dev. }\end{array}$ & Skewness & Skewness & Kurtosis & Kurtosis \\
\hline EDU & 115 & 1,61 & 2 & 1 & 4 & 1 & 2 & 1 & 0,669 & 0,806673 & 0,225511 & 0,3241 & 0,4473 \\
\hline \multicolumn{14}{|l|}{$\mathrm{CZ}$} \\
\hline & & & & & & Lower & Upper & $\begin{array}{l}\text { Quar } \\
\text { tile }\end{array}$ & & & Std.Err. & & Std.Err. \\
\hline & \begin{tabular}{|l} 
Valid \\
$\mathrm{N}$ \\
\end{tabular} & Mean & $\begin{array}{l}\mathrm{Me} \\
\text { dian }\end{array}$ & Min & Max & $\begin{array}{l}\text { Quar } \\
\text { tile }\end{array}$ & $\begin{array}{l}\text { Quar } \\
\text { tile } \\
\end{array}$ & Range & $\begin{array}{l}\text { Std. } \\
\text { Dev. }\end{array}$ & Skewness & Skewness & Kurtosis & Kurtosis \\
\hline EDU & 114 & 1,63 & 2 & 1 & 5 & 1 & 2 & 1 & 0,731 & 1,668155 & 0,226473 & 4,7120 & 0,4492 \\
\hline \multicolumn{14}{|l|}{$\mathrm{HU}$} \\
\hline & & & & & & Lower & Upper & $\begin{array}{l}\text { Quar } \\
\text { tile }\end{array}$ & & & Std.Err. & & Std.Err. \\
\hline & $\begin{array}{l}\text { Valid } \\
\mathrm{N} \\
\end{array}$ & Mean & $\begin{array}{l}\mathrm{Me} \\
\text { dian }\end{array}$ & Min & Max & $\begin{array}{l}\text { Quar } \\
\text { tile } \\
\end{array}$ & $\begin{array}{l}\text { Quar } \\
\text { tile } \\
\end{array}$ & Range & $\begin{array}{l}\text { Std. } \\
\text { Dev. }\end{array}$ & Skewness & Skewness & Kurtosis & Kurtosis \\
\hline EDU & 96 & 1,65 & 1 & 1 & 5 & 1 & 2 & 1 & 0,818 & 1,571471 & 0,235724 & 3,6313 & 0,4673 \\
\hline \multicolumn{14}{|l|}{ PL } \\
\hline & & & & & & Lower & Upper & $\begin{array}{l}\text { Quar } \\
\text { tile }\end{array}$ & & & Std.Err. & & Std.Err. \\
\hline & $\begin{array}{l}\text { Valid } \\
\mathrm{N}\end{array}$ & Mean & $\begin{array}{l}\mathrm{Me} \\
\text { dian }\end{array}$ & Min & Max & $\begin{array}{l}\text { Quar } \\
\text { tile }\end{array}$ & $\begin{array}{l}\text { Quar } \\
\text { tile }\end{array}$ & Range & $\begin{array}{l}\text { Std. } \\
\text { Dev. }\end{array}$ & Skewness & Skewness & Kurtosis & Kurtosis \\
\hline EDU & 100 & 1,53 & 1 & 1 & 4 & 1 & 2 & 1 & 0,593 & 0,915811 & 0,24138 & 1,4665 & 0,4783 \\
\hline
\end{tabular}

Source: own research

Taken together the positive answers (definitely yes and yes), it can be concluded that up to 92.53\% of the students from V4 countries consider it necessary to be educated in the area of environmental protection, which is a very positive outcome. $6.00 \%$ of students were unable to comment on it, and only $1.47 \%$ percent of the students think that they do not need to get educated in this area, which can also be seen as positive. The rank of students' awareness and their need to be educated in the field of environmental protection was determined on the basis of calculated means. The students from Poland reached the first place again with a value of 1.53; the students from Slovakia reached the second place with a value of 1.61; the third place is occupied by students from the Czech Republic with a value of 1.63 and the fourth place belongs to students from Hungary with a value of 1.65.

The dependence between the level of knowledge of the chosen environmental policy tool and the need to be educated has also been studied within the research. To determine whether there is such a dependence a following hypothesis was established.

H1: The lower the level of knowledge about the chosen environmental policy tool the students have, the greater need they have to be educated in the field of environmental protection.

For its confirmation or rejection the gamma Kendall correlation coefficient was used since the data obtained from all four samples of surveyed students showed an uneven distribution. 


\section{Macrothink}

Table 8 Dependence between the level of knowledge and the need to learn

\begin{tabular}{|l|l|l|l|l|}
\hline & Valid & & & \\
\hline & $\mathrm{N}$ & Gamma & $\mathrm{Z}$ & $\mathrm{p}$-level \\
\hline ISO \& EDU & 425 & 0,031352 & 0,659904 & 0,509315 \\
\hline EMAS \& EDU & 425 & 0,085038 & 1,718048 & 0,085788 \\
\hline LCA \& EDU & 425 & 0,021903 & 0,450663 & 0,652233 \\
\hline EPE \& EDU & 425 & 0,017156 & 0,358949 & 0,719634 \\
\hline EL \& EDU & 425 & 0,013201 & 0,270974 & 0,786411 \\
\hline CSR \& EDU & 425 & 0,008398 & 0,171815 & 0,863583 \\
\hline
\end{tabular}

Source: own research

Based on the results obtained by gamma Kendall correlation coefficient this hypothesis was rejected.

Kendall coefficient in all selected environmental policy tools that have been put in mutual relation to the need to be educated, exhibits very low values, i.e. there is no statistically significant relationship between the level of knowledge and the need to be educated. Based on these results it can be concluded that students from all V4 countries feel the need to be educated in the field of environmental protection, regardless of how much knowledge they have of the subject area.

A connection between the level of awareness of a selected environmental policy tool and the effort of future managers to motivate the subordinates towards the environment protection was searched for in the next part of the research. The hypothesis H2 was established to determine a possible connection.

$\mathrm{H} 2$ : The level of knowledge about individual environmental policy tools significantly influences the effort to motivate the future subordinate employees.

The analysis of variance was performed to assess the suitability of obtained data and the choice of appropriate method of inductive statistics.

Table 9 Summary Table of Means

$\mathrm{N}=434$ (No missing data in dep. var. list) (MOT - motivation)

\begin{tabular}{|l|l|l|}
\hline & MOT & MOT \\
\hline & Means & Std.Dev. \\
\hline G_1:1 & 1,621622 & 0,805847 \\
\hline G_2:2 & 1,711111 & 0,690944 \\
\hline G_3:3 & 1,846154 & 0,821663 \\
\hline G_4:4 & 1,976471 & 0,801434 \\
\hline G_5:5 & 1,91358 & 0,911009 \\
\hline All Grps & 1,817972 & 0,813597 \\
\hline
\end{tabular}

Brown-Forsythe Test of Homog. of Variances

Marked effects are significant at $p<, 05000$

\begin{tabular}{|l|l|l|l|l|l|l|l|l|}
\hline & SS & df & MS & SS & df & MS & & \\
\hline & Effect & Effect & Effect & Error & Error & Error & F & p \\
\hline MOT & 0,683451 & 4 & 0,170863 & 177,7428 & 429 & 0,414319 & 0,412394 & 0,799735 \\
\hline
\end{tabular}


Source: own research

The testing of homogeneity of variance showed that for the detection of depending on two variables - the level of knowledge of the environmental policy tools and future willingness to motivate subordinates it is appropriate to use ANOVA.

Table 10 Analysis of Variance (Marked effects are significant at $\mathrm{p}<, 05000$ )

\begin{tabular}{|l|l|l|l|l|l|l|l|l|}
\hline & SS & df & MS & SS & df & MS & & \\
\hline & Effect & Effect & Effect & Error & Error & Error & F & p \\
\hline MOT & 6,839057 & 4 & 1,709764 & 279,7808 & 429 & 0,65217 & 2,621656 & 0,034425 \\
\hline
\end{tabular}

Hypothesis H2 was confirmed. The value of the correlation coefficient is $0.034425 \mathrm{p}$, and thus evaluated data are significant at $\mathrm{p}<, 05000$, which means that there is a significant correlation between the level of knowledge about environmental policy tools and their impact on the willingness of future managers to motivate the future subordinates towards environmental protection. Since ANOVA captured significant differences in analysed data the level of knowledge about selected environmental policy tools - every single tool was analysed in connection with the willingness to motivate employees. A post hoc test, namely the Fisher LSD test, was used for the analysis. The values obtained ranged from 0.000595 at p ECO to p .017419 in EMAS. The evaluated data are significant at $p<.05000$. The most significant differences were found in responses definitely yes (definitely I have a knowledge about the environmental policy tool) and yes.

Table 11 Analysis of Variance (Marked effects are significant at $\mathrm{p}<, 05000$ )

\begin{tabular}{|l|l|l|l|l|l|l|l|l|}
\hline & SS & df & MS & SS & df & MS & & \\
\hline & Effect & Effect & Effect & Error & Error & Error & F & p \\
\hline MOT/ECO & 12,78061 & 4 & 3,195153 & 273,8392 & 429 & 0,63832 & 5,005567 & 0,000595 \\
\hline
\end{tabular}

\begin{tabular}{|l|l|l|l|l|l|l|l|l|}
\hline & SS & df & MS & SS & df & MS & & \\
\hline & Effect & Effect & Effect & Error & Error & Error & F & p \\
\hline MOT/EMAS & 7,882245 & 4 & 1,970561 & 278,7376 & 429 & 0,649738 & 3,032856 & 0,017419 \\
\hline
\end{tabular}

Based on the results, it can be stated that the more knowledge the students have about the environmental policy tools the more willing they will be to motivate their future subordinate to protect the environment and vice versa, the less knowledge they will have, the less need they will feel to motivate the subordinates towards the environmental protection. This finding also supports the view of the authors that teaching about environmental issues should be also implemented by business schools.

The paradigm shift is needed in the field of higher education and training of future managers. The main motive of sustainable development are the expectations of the countries of the European Union, whereas these expectations need to be reconciled. Business schools should also educate on sustainable development and undertake research in this area. The institutions of higher education should contribute to the national environmental protection by knowledge and implementation of individual environmental policy tools. The objective of higher education is to have a realistic scope, to contain the necessary knowledge and to lead towards attitudes necessary for application of tools for sustainable development. There is a 
call for the creation of teaching materials, which play an important role in education for sustainable development and which include the issue of sustainable consumption, energy efficiency, cleaner production and the like. Through information and communication technologies and application programmes the access to education in the field of environmental protection should be expanded.

The cornerstones of education for sustainable development should be interdisciplinary and on the values based teaching that promotes system thinking and teaching and develop new knowledge, skills and attitudes. It should place emphasis on creative thinking, innovation and long-term perspective, especially our own responsibility towards future generations. Education for sustainable development is not a separate subject; it is rather a set of fundamental principles and values, such as justice, equality, tolerance, self-reliance and responsibility that need to be communicated more widely across different subjects. Education for sustainable development can also play a role in developing the competence necessary for increasing employment. Because skills related to sustainable development are best obtained on the basis of personal experience, the learning process should be focused as much as possible on inclusive education, proactive approach and motivation. In higher education the education for sustainable development should be aimed at developing more targeted skills and competences that are needed for different professions, as well as to address issues such as responsible decision-making of individuals and communities, and corporate social responsibility.

\section{Proposal for a system of education for sustainable development}

Dynamics of change - not only legislative, or social - determines the need for continued efforts to improve the education through modifying the contents of established courses and introducing new ones, so that on the one hand they reflect the current events in the external environment, current trends in education and implementation of scientific results into the educational process, on the other hand, it is also necessary to take into account the growing efforts to maximise the employability of graduates in the field. On this basis, the authors propose a system of education for sustainable development at business schools, launched at three interconnected levels.

1. Individual study programmes

Environmental education should create such a combination of theoretical knowledge, skills and any experience so that graduates could (although after some adaptation time) fully operate primarily in targeted areas of their professional careers. Therefore, it is desirable to establish, when offering study programmes of higher education of economic and managerial focus, also an independent study program, which would provide teaching of complex issues of environmental protection and sustainable development.

\section{Subjects in other study programmes}

Subjects dealing with environmental issues should represent a broad spectrum of compulsory - optional or optional subjects in different study programmes of economic field. This category includes subjects such as Environmental economics, Quantification of potential damage in the regions, Environmental Policy, Environmental Education, Business Ethics, and more.

3. Selected chapters within subjects of the main focus 
Integration of issues of environmental protection and sustainable development is possible even in the current composition of subjects in the study programmes that are not explicitly environmentally oriented in the form of selected chapters devoted to environmental issues. Such an integrated method allows to connect the main theme of the subject to environmental issues, what appropriately enlarges the horizon of perception of the issue. There is a large amount of examples of implementation of this form of environmental education, yet it is very difficult to watch the real number of selected chapters within individual subjects devoted to environmental issues. Here are a few examples of subjects in which it is possible to include specific chapters dealing with the issue of sustainable development. In the subject International Management it is possible to include a chapter on the issue of social responsibility of organisations in which students can become familiar with this concept and understand the basic principles that can increase the economic efficiency and enhance the goodwill of the company while a favorable impact on the environment. Another example may be the subject National economy, where students can become familiar with the impact of economic activity on the environment; there is also possible to implement the principles of environmental responsibility in individual sectors of the national economy taking into account their specificities. Other subjects where the environmental themes could be incorporated are: Project management, Marketing, Management, Management of risk and change, Marketing communication, International trade and business culture, and more.

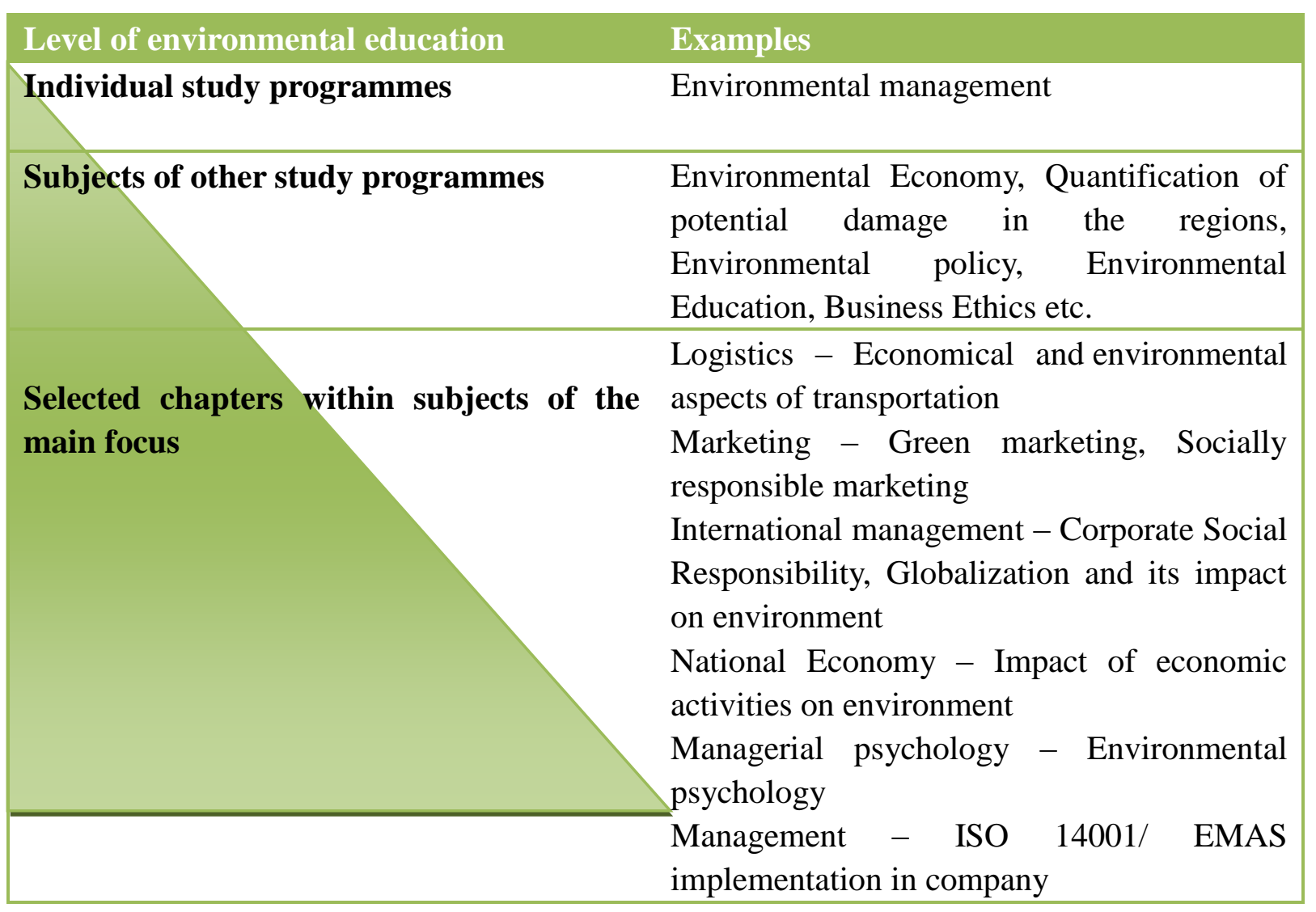

3.1 Methods of active learning for sustainable development

Under the proposed system of education for sustainable development such teaching methods 
should be applied that allow students to individually and actively address the problems of environmental protection. The methods and organisational forms of education for sustainable development create a process that promotes independence and reflection. They draw on constructivist educational theory, which simply says that the students build their knowledge alone. Education for sustainable development therefore commonly uses the methods of active learning (Průcha et al., 2003). As their name suggests, the focus of these methods is the student's intrinsic activity. Such methods may include: project-based learning, situational learning, locally based learning, experiential learning and engaged learning. These methods are best applied in direct contact with the environment, which is closely related to the content of curriculum. Education for sustainable development is therefore often realised through various excursions, practices, discussions, experimentation, simulation on computers, etc.

\section{Debate}

The results of the implementation of education for sustainable development in Europe in order to fulfill the Vilnius strategies were discussed at the conference in Belgrade in 2009. As the weakest links of implementation were specified in particular: lack of teaching materials, under-utilization of the potential of universities and research institutions, lack of qualified teachers, low awareness about the concept of sustainable development and education for sustainable development, underdeveloped interdepartmental and interdisciplinary cooperation in education for sustainable development and closed character educational systems for the application of a holistic approach, lack of understanding or unclear definitions of education for sustainable development and its relationship to environmental education and training. (Vošahlíková, 2011)

The research results have shown that it is very important to implement issues of environmental protection and sustainable development into appropriate subject curriculums, especially at universities. If this issue is presented to students through adequate and motivating teaching methods, it can promote awareness, understanding and students' interest in environmental protection, as stated by De Haan (1998), Vošahlíková (2011), and others who agree that environmental education of managers should promote awareness, understanding and interest which motivate students to environmental activities and environmentally sustainable behaviour in their personal, social and working life. The acquired knowledge and skills in this area will enable them to more easily find a job in the labor market in the context of the green economy. Even if in the case of future managers this will not be a direct employment in the green economy, but it will be an indirect employment in the green economy. The future managers will be able to implement sustainable development projects and the development of a green economy in the management of the company. Universities can prepare future graduates for so called jobs with green qualification, Green Enhanced Skills Occupations, that require changes of individual activities, skills and so on. An important role in protecting the environment also plays the personal responsibility of managers. We can only agree with Randsa's (2009) opinion, who refers to the principle of personal responsibility through which individuals contribute to sustainable development. And this principle of responsibility should be developed in students also at universities through 
education and training in environmental protection. Kravčáková (2007) states that motivation plays an important role in managers' work. Working motivation will be also important for the future managers who will be employed in such positions where they will be able to implement individual environmental policy tools into practice of firms, which they will lead. University teachers should possess the adequate knowledge and competences in order to be able to teach the issues of sustainable development. De Haan (1998) draws three key competences, which are typical for education for sustainable development.

Methodological competence - a skill to specifically process and apply factual knowledge. This competence allows to systematically process problems and to draw their creative solutions (new information, procedures, etc.), to identify interdependencies and dependencies on the framework conditions for the formation and problem solving, and to reflect the hazards and risks of the proposed solution.

Social competence - includes the possibility to seek solutions to the problem together with other people, to be able to constructively as well as critically collaborate with these people. This also means to be able to empathise, to show solidarity and to be able to get involved for others.

Personal competence - which primarily means the ability to organise one's own daily activities according to one's own objectives, that are satisfactorily met. Another part of this competence is the ability to further become better, to propose new ideas in a variety of forms of expression and share them with others. Finally, personal competence involves a complex ability of self-reflection that is to develop a personal scale of values, to clarify one's own position in daily happenings in touch with people and with nature.

The role of teachers is to develop these competences in students through adequate teaching methods to sustainable development.

In a meta-analysis of environmental education interventions, Zelezny (1999) found that "improved environmental behaviours" are most likely to result when the intervention targets young participants.

We envision three possible outcomes of such a conversation:

(1) Helping students develop the knowledge, skills and motivation to improve how humanity interacts with the Earth and environment is important, and should be done in science classes.

(2) Helping students develop the knowledge, skills, and motivation to improve how humanity interacts with the Earth and environment is important, and should be done in school. Science classes can do their part by developing students' knowledge of natural Earth systems, but many aspects of human/environment interactions are more appropriate for other parts of the curriculum, including Geography, Consumer Science, and Technology.

(3) Changing how humanity interacts with the Earth and environment is not an appropriate goal for public schools, either in science or elsewhere in the curriculum. (Kastens, Turrin, 2006).

Education for sustainable development is still being formulated as a broad and complex concept involving interconnected ecological, economic and social issues. It extends the concept of environmental education, which includes the increasingly wider range of development issues and the green economy and also encompasses various elements of 
education on development issues and other thematic forms of education.

\section{Conclusion}

Education and training for sustainable development requires decoupling of providing the knowledge to discussing the problems and finding possible solutions. Therefore, education should maintain a traditional focus on teaching individual subjects but also open up opportunities for multilateral and interdisciplinary exploration of real-life situations. This should influence the structure of study programmes and teaching methods, which requires a transformation of teachers from carriers only and students from recipients only so that both groups form a team.

There are a lot of opportunities to use education and training for sustainable development to induce changes in individual consciousness, but their implementation will require fundamental changes in approach to education also at business schools.

\section{Acknowledgement}

The study was supported by KEGA 032PU-4/2014.

\section{References}

Adamišin, P. (2012). Environmental education as a means to environmental awareness increase of company and environment quality. In Proceedings of the International scientific correspondence conference EAEP 2012, Prešov : Prešovská univerzita v Prešove, 2012, p. 7-12, ISBN 978-80-555-0655-5.

Azapagic, A., Perdan, S., Clift, R. (2004). Sustainable development in practice: Case studies for Engineers and Scientists. John Wiley \& Sons, Ltd. ISBN: 0-470-85609-2.

Bellan, P. (2010). Zelené pracovné miesta v kontexte trhu práce SR. [Online] Available: www.sspr.gov.sk/IVPR/images/IVPR/vyskum/2010/Bellan/VU-Bellan.pdf (August 7, 2014)

Egri, C.P. , Rogers, K. S. (2003). Teaching about the natural environment in management education: New directions and approaches. Journal of Management Education

Fazekašová, D. (2007). Informačné zdroje v ekológii a v environmentálnej výchove. In Inovatívne prístupy k problematike environmentálnej výchovy. Prešov : Rokus, 2007. S. 96-107. ISBN 978-80-89055-73-9

Gál, Z., Zsibók, Z. (2012). Engagement of mid-range universities: Adopting European models and best practices in Hungary. AUDEM: The International Journal of Higher Education and Democracy 2:(1) pp. 94-120.

Haan, Gerhard de. (1998). Bildung für Nachhaltigkeit, Schlüsselkompetenzen, Umweltsyndrome und Schulprogramme. Berlin, 1998, ISBN 3-927064-50-5.

Halašová, M. (ed.) (2009). Výchova a vzdelávanie k trvalo udržatel’nému rozvoju. Zborník príspevkov a závery z 5 . národnej konferencie s medzinárodnou účast'ou konanej 21.-22. januára 2009 v Banskej Bystrici, Banská Bystrica 2009, ISBN 978-80-8083-876-8

Halašová, M. (ed.) (2009). Výchova a vzdelávanie k trvalo udržatel’nému rozvoju. Zborník príspevkov a závery z 5 . národnej konferencie s medzinárodnou účast'ou konanej 21.-22. januára 2009 v Banskej Bystrici, Banská Bystrica 2009, ISBN 978-80-8083-876-8

Hilbert, H. (2007). Súčasný stav a perspektívy vzdelania v oblasti TUR na Slovensku, 
Ekológia a environmentalistika, 2007, Zvolen

Huggins, R., Kitagawa, F. (2009). Devolution and knowledge transfer from universities: Perspectives from Scotland and Wales. Discussion Paper: Impact of Higher Education Institutions on Regional Economies Initiative. Cardiff: University of Wales Institute Huttmanová, E., Adamišin, P., Hronec, O. (2009). Mozliwości środowiskowego ksztalcenia i wychowania w procesie edukacyjnym w Slowacji. In: Edukacja biologiszna i środowiskowa. nr. 4 (32) 2009. p. 5 - 10. ISSN 1643-8779.

Chovancová, J. (2012). Systémy environmentálneho manažérstva, Prešov: Prešovská univerzita v Prešove, 2011, 98 s. ISBN:978-80-555-0485-8

Informace orgánu, insitucí a jiných subjektu Evropské unie Rada. Závěry Rady z 19. listopadu 2010 o vzdělávání pro udržitelný rozvoj (2010/C 327/05) [Online] Available: http://eur-lex.europa.eu/LexUriServ/LexUriServ.do?uri=OJ:C:2010:327:0011:0014:CS:PDF (July 20, 2014)

Jurková, J., Ferencová, M. (2013). Environmentálny aspekt spotrebitel'ského správania v procese edukácie. In: Didaktika, 1/2013, s. 19-21. Bratislava: Iura Edition, 2013. ISSN $1338-2845$

Kastens, Kim A. Turrin, Margaret. (2006). Journal of Geoscience Education 54.3 (May 2006): 422-436 To What Extent Should Human/Environment Interactions Be Included in Science Education?

Kindlmannová, J., Vošahlíková, T. (2010). Podpora vzdělávaní k udržitelnému rozvoji. [Online] Available: http://www.vuppraha.cz/wp-content/uploads/2010/02/Studie_podpora_VUR_final.pdf (July 22, 2014)

Krasny, E. M., Lundholm, C., Plummer, R. (2010). Environmental education, resilience, and learning: reflection and moving forward. Environmental Education Research, Vol. 16. Nos. 5-6, October 2010, 665-672, ISSN 1350-5622

Kravčáková, G. (2007). Metódy manažmentu pracovnej motivácie. In: Zborník vedeckých prác katedry ekonómie a ekonomiky ANNO 2007. - Prešov : Prešovská univerzita v Prešove, 2007. - ISBN 9788080686574. - S. 86-102.

Majerník, M., Bosák, M., Chovancová, J. (2006). Educational concept of eco-management and audit scheme (EMAS) at Slovakian universities. Globalne i regionalne problemy ochrony srodowiska : praca zbiorowa. Gdansk : Wydawnictwo Gdanskiej wyzszej szkoly administracji, 2006. p. 225-236 ISBN:83-89762-06-4

Majerník, M., Chovancová, J., Hodolič, J. (2009). Environmentálne manažérske systémy. Skalica : Stredoeurópska vysoká škola v Skalici, 2009, 160 s. ISBN:978-80-89391-05-9

Majerník, M., Chovancová, J., Juríková, J. (2008). Implementácia úloh Akčného plánu výchovy a vzdelávania k TUR do vedecko-výskumných a pedagogických aktivít Katedry environmentalistiky a riadenia procesov, TU Košice - identifikácia bariér a príležitostí. Výchova a vzdelávanie $\mathrm{k}$ trvalo udržatel'nému rozvoju na slovenských vysokých školách : zborník príspevkov zo seminára. Bratislava: Univerzita Komenského v Bratislave, Prírodovedecká fakulta, p. 50-55, ISBN:978-80-223-2581-3

Mintu, A. T., Lozada, H. R., Polonsky, M. J. (1993). Environmental consciousness and the business curricula: Some thoughts. Journal of Teaching in International Business, 5, 
XV-XVIII

Nemzeti Környezeti Nevelési Stratégia Felsöoktatás Lükö, I. [Online] Available: http://mkne.hu/NKNS_uj/layout/NKNS_layout.pdf (August 18, 2014)

Orr, D. W. (1992). Ecological literacy: Education and the transition to a postmodern world. Albany, State university of New York Press.

Orr, D. W. (1994). Earth in mind: On education, environment, and the human prospect. Washington DC: Island Press.

PRŮCHA, J. et al. (2003). Pedagogický slovník. Vyd. 4., aktualiz. Praha : Portál, 2003. ISBN 80-7178-772-8

Narodowa Strategia Edukacji Ekologiczne, Druk: Wydawnictwo Drukarnia ÑLIBER̂̂, Lublin Warszawa 2001 ISBN 83-86564-51-2 [Online] Available: http://dzieci.mos.gov.pl/index.php?app=docs\&action=get\&iid=1275 (June 8, 2014)

Rands, G.P. (2009). A principle-Attribute matrix for Environmentally Sustainable Management Education and Its Application. The case for Change-Oriented Service-Learning Projects. Journal of Management Education, Vol. 33, Mumber 3, June 2009, 296-322, ISSN 1052-5629

Teplická, K. (2007). Moderné trendy v environmentálnom manažérstve. Manažment v teórií a praxi. 1-2/2007 ISSN 1336-7137

Terek, J. (2009). Ako d'alej v environmentálnej výchove. In Sacrum a príroda : zborník príspevkov z medzinárodnej vedeckej konferencie. Kraków : Wydawnictwo Naukowe, 2009. S. 74-79. ISBN 978-83-74-38-211-3

United Nations: Agenda 21 - Action plan of the United Nations with regard to sustainable development, Product of the UN Conference on Environment and Development (UNCED) held in Rio de Janeiro, Brazil, 1992 online: http://sustainabledevelopment.un.org/ content/documents/Agenda21.pdf.

Vošahlíková, T. (2011). Základy vzdělávaní pro udržatel'ný rozvoj. [Online] Available: http://clanky.rvp.cz/clanek/o/z/12983/ZAKLADY-VZDELAVANI-PRO-UDRZITELNY-RO

ZVOJ.html/ 2011 (July 14, 2014)

Vošahlíková, T. (2011). Zahraniční přístupy k implementaci vzdělávání pro udržitelný rozvoj. [Online]

Available: http://clanky.rvp.cz/clanek/o/z/12733/ZAHRANICNI-PRISTUPY-K-IMPLEMENTACI-VZD ELAVANI-PRO-UDRZITELNY-ROZVOJ.html/ 2011 (July 14, 2014)

Ward, H. (1999). Why is service learning so pervasive in environmental studies programs? In. H. Ward (Ed.) Acting localy: Concepts and models for service-learning in environmental studies (pp. 1-12) Washington DC: American Association for Higher Education

Zelezny, L.C., (1999). Educational interventions that improve environmental behaviors: a meta-analysis: Journal of Environmental Education, v. fall, p. 5.

\section{Copyright Disclaimer}

Copyright for this article is retained by the author(s), with first publication rights granted to the journal.

This is an open-access article distributed under the terms and conditions of the Creative Commons Attribution license (http://creativecommons.org/licenses/by/3.0/). 